\title{
The Politics of Law of Pancasila-based Democracy in Indonesia as the World's Third Largest Democracy
}

\author{
Fifiana Wisnaeni \\ Ratna Herawati \\ Faculty of Law, \\ Diponegoro University, \\ Semarang, Indonesia
}

DOI: https://doi.org/10.36941/ajis-2020-0059

\begin{abstract}
The Indonesian Constitution explicitly states that Indonesia is a country that manages the democratic political system. In the practice of managing the State, democracy that takes place in Indonesia always changes following the development of the Indonesian constitutional system. The aim of this research is to investigate the political development of democratic law in the world's third largest democracy and the ideal democratic system for Indonesia at this time. The research method used is normative juridical, with descriptive analytical research specifications and secondary data types. The data collection method was carried out through a literature study and research results were analyzed by qualitative methods. The results showed that the ideal democracy for the Indonesian state was Pancasila democracy as stated in the Preamble to the Constitution, which stated that democracy was led by wisdom in the deliberative representation and stated that sovereignty was in the hands of the people and implemented according to the Constitution.
\end{abstract}

Keywords: democracy, constitutional system, politics of law, Indonesia

\section{Introduction}

In state theory, democracy is defined as a form of state organization in which the government is carried out by the people, as opposed to a monarchie government or an oligarchy government (Wahyono, 1989). Related to this, it can be said that Indonesia is a country that embraces a democratic political system because in its constitution it explicitly states that sovereignty is in the hands of the people. Democracy is a term that is loaded with meaning and interpretation. One thing that is certain is that understanding is closely linked to the social system that supports it (Muladi, 1997). Thus, it would appear that, in addition to containing universal elements or common denominator, democracy also contains contextual contents inherent in a particular social system or cultural relativism. In this case it is often said that perhaps not a single word has been given more meaning than democracy. In Indonesia, there have been several changes in the democratic system in line with the development of Indonesian state administration (Saraswati et al., 2020). Broadly speaking, the development of state administration in Indonesia can be divided into periods after independence, the era of the new order government and the reform order (Parasong, 2014).

According to Hidayat (2006), democracy in Indonesia can be divided into parliamentary democracy (1945-1949), guided democracy (1959-1966), and Pancasila democracy (1966-1998), 
democracy in the reformation era (1998-present). It can be seen that democracy in Indonesia is strongly influenced by the development of the constitutional system in Indonesia. Furthermore, Mahfud (2009) states that legal politics refers to legal policy or official policy lines regarding the law that will be enforced either by making new laws or by replacing old laws, in order to achieve the goals of the country. The change in democracy in Indonesia is closely related to the political politics that apply when democracy is implemented in accordance with its period (Mahfud, 2012). Politics of law is manifested in changes in law, both in the form of making new laws and replacing old laws (Budiardjo, 2008).

By looking at the development of democracy in Indonesia, since Indonesia's independence until now, this study seeks to investigate the development of democracy and Indonesian state administration from the perspective of legal politics that now prevails in Indonesia. The ideal question is the suitability of the political system and state administration for a multicultural Indonesia. Theoretically, the adoption of democracy and the state administration system can ultimately lead to the realization of the ideals of the country, namely creating a just and prosperous society based on the Pancasila and the Constitution of the Republic of Indonesia.

\section{Methods}

The method of approach in this study is normative juridical, which is an approach that uses the concept of positivist legis which states that law is identical with written norms created and enacted by authorized institutions or officials (Marzuki, 2003). In addition, this concept also views law as a normative system that is autonomous, closed and independent of people's lives (Soemitro, 1988).

From the research specifications, this research is analytical descriptive, namely describing, describing or revealing data that has relevance to the problem (Alwasilah, 20o8). Based on the types and methods of data collection, the types of data from this study are secondary data. Secondary data consists of primary legal materials, in the form of laws and regulations consisting of the constitution that was and is currently in force in Indonesia. Secondary legal material in the form of books and literature related to the problem under study and primary legal material in the form of the internet. In accordance with the type of data, the data collection method used is library research.

Data analysis in this study was carried out with qualitative data analysis. Qualitative methods are research procedures that produce descriptive data in the form of written or spoken words from people and observable behavior (Moleong, 2014). All data needed is processed and arranged systematically, so that it can produce conclusions in accordance with the problems and research objectives delivered in a descriptive form.

\section{History of Indonesian Democracy and Constitution}

The development of democracy in Indonesia is closely related to the development of Indonesian state administration, which can be divided into four main developments. First, presidential democracy (August 17, 1945-Nov. 11, 1945). Since Indonesia became independent and sovereign as a country on August 17, 1945, the nation founders through the 1945 Constitution which was passed on August 18, 1945 have determined that the Unitary State of the Republic of Indonesia adheres to the democracy, where sovereignty is in the hands of the people and fully implemented by the People's Consultative Assembly. These provisions can be seen in the formulation of Article 1 paragraph (2) of the 1945 Constitution which states that sovereignty is in the hands of the people and is carried out entirely by the People's Consultative Assembly. Thus, it also means that the Republic of Indonesia is classified as a country that embraces the representative democracy.

The second development was Parliamentary democracy starting with the issuance of the November 14, 1945 announcement by the President, which contained a new cabinet arrangement under Prime Minister Sutan Syahir, accountable to Parliament, namely the Central Indonesian National Committee/KNIP. Based on the announcement of November 14, 1945 the President lost his 
position as Head of Government, because in the parliamentary system of government carried out by the Cabinet led by a Prime Minister responsible to Parliament/KNIP). The center of executive power has shifted from the President to the Prime Minister, because the day-to-day responsibilities of the government are in the hands of the Minister who will then be held accountable to Parliament and the President is only the head of state. There has been a fundamental change in the state administration in the political system o from a presidential system to a parliamentary system without making changes to the Constitution. At the time the parliamentary system came into force, the people had begun to enjoy basic rights freely including the right to assemble and associate by establishing and becoming members of political parties as evidenced by the emergence of political parties and a number of youth and women's mass organizations that were wrongly affiliated one party. The main function of the party was to join the government to win the independence revolution by instilling state awareness and the spirit of anti-imperialism and colonialism. Meanwhile, other basic elements of democracy cannot be fully realized. Accountability of office holders elected by the people, rotations of power, open political recruitment and general elections cannot be carried out (Feith \& Castles, 2007).

Third is guided democracy emerged because, since the end of the general election in 1955 . Political parties in this time had been very much oriented towards their own ideological interests and paid less attention to national political interests as a whole. Therefore, Sukarno as the President of the Republic of Indonesia then threw up the idea that parliamentary democracy was incompatible with the personality of the Indonesian nation imbued with a spirit of kinship and mutual cooperation. In an effort to overcome the conflict that had the potential to disintegrate the Republic of Indonesia at that time, President Soekarno finally changed the democratic system from parliamentary democracy to the leading democracy marked by the issuance of the Presidential Decree on July 5, 1959 (Lev, 2009). The contents of the Presidential Decree included re-enacting The 1945 Constitution. Since the issuance of the Presidential Decree, since then the guided democracy model has been implemented which is claimed to be in accordance with the ideology of the State of Pancasila and integralisticism which teaches about unity between the people and the state.

The fourth is Pancasila Democracy (1966 - 1998) which began with Soeharto's appointment as President replacing Soekarno as the 2nd President of Indonesia and applying a different model of democracy, namely called New Order's Pancasila Democracy, to confirm the claim that the democratic model this is actually in accordance with the ideology of the Pancasila state (Morfit, 1981). The implementation of the New Order democracy was marked by the issuance of the March 11, 1966 Order, the New Order was determined to implement the Pancasila and the Constitution in a pure and consistent manner. The beginning of the New Order gave new hope to the people of development in all fields through the Five Year Development Plan. However, a visible development is the widening gap between state power and society. The New Order state manifested itself as a strong and relatively autonomous force, and while society was increasingly alienated from the environment of power and policy formulation processes, through centralized authority, minimization of political parties, and the role of the military (Crouch, 1972).

The fifth is democracy in the reformation era (1998-present). The end of the New Order period was marked by the transfer of power from President Soeharto to Vice President BJ Habibie on May 21, 1998 (Lindsey, 2002). With the fall of the New Order regime, the structuring of the constitutional system towards the consolidation of the democratic system in Indonesia began (O'Rourke, 2002). The most important consolidation is by making changes and replacing various laws and regulations which are considered not to provide space for democratic life and the principles of popular sovereignty with amendments to the constitution, decentralization of regional government, and the formation of democratic supporting institutions. Amendments to the Constitution are carried out as the main prerequisite for the implementation of a democratic constitutional system (Horowitz, 2013). This is because the systematics contained in the old constitution did not provide sufficient space to develop the concept of democratic governance and the principle of the sovereignty of the people. 


\section{Politics of Law in Democracy and Constitutional System}

Democracy is a system of government in which all citizens have equal rights in decision making that can change their lives. Democracy allows citizens to participate, either directly or through representation in the formulation, development and formation of the law (Michels \& De Graaf, 2010). Democracy includes social, economic and cultural conditions that allow for the practice of free and equal political freedom. Democracy can also be interpreted that the people have the highest power in a country. A democratic government is different from the form of oligarchy, and monarchy government in which one or limited person holds power (Bastian, 2015). Democracy has several principles, such as equality between citizens in which every citizen has equality in political practice, citizen involvement in making political decisions and recognition of freedom by the state.

In detail, to implement democratic values, it is necessary to hold several important institutions. First, there are state institutions such as the executive government and the House of Representatives that have groups and interests in society and are elected by free elections and on the basis of at least two candidates for each seat. This House of Representatives conducts oversight and controls that allow constructive opposition and allows continuous evaluation of government policies (Sorensen, 1993).

Second is a party organization that includes one or more political parties, where the parties have a continuous relationship between the general public and its leaders (Pradityo, 2018). Third is the press, mass media and civil society who are free to express their opinions (Hidayat, 2006). Fourth is a free judicial system to guarantee the rights of speeches and maintain justice (Butt, 2015).

In the practice of Indonesian constitutional life since the early days of independence until today, representative democracy implemented in Indonesia consists of several models of representative democracy that differ from one another. This is the implication of the development of the state administration of Indonesia, starting from post-independence to the reform era. In this case, the development of state administration in Indonesia is in line with changes to the Basic Law which is used as the highest legal basis. In terms of politics of law, changes and amendments to the Constitution in Indonesia also have implications for the development of democracy in Indonesia (Nggilu, 2015).

This is in accordance with the opinion of Mahfud (2009) which states that law as a political product is not only law in the sense of law, but also includes other laws, including the constitution and the Constitution. Furthermore, Mahfud (2009) also states that politics as an independent variable is extreme divided into two forms of democratic politics and authoritarian politics. Meanwhile, the law as a dependent variable is distinguished from responsive law and orthodox law. A democratic legal configuration will give birth to responsive laws, while an authoritarian political configuration will give birth to orthodox or conservative laws. At present, the reform era has been going on for 22 years. The state administrators always strive to realize a democratic government based on the 1945 Constitution of the Republic of Indonesia, among others by making various changes related to legal politics relating to the implementation of democracy in Indonesia.

At present the party system used in Indonesia is multi-party and the electoral system used to elect legislative members is proportional to the list of open candidates, so it is very difficult to turn a single party into a single party. Article 7 of the 1945 Constitution expressly states that the President and Vice-President shall hold office for five years and thereafter may be re-elected in the same office, for only one term. Based on the provisions of Article 7 of this Constitution, it is not possible for the President in Indonesia to hold a position as President for a long period of time.

Hidayat (2015, interview) states that the most appropriate democracy for the Indonesian state is Democracy as stipulated in the Preamble to the Constitution Paragraph IV which states that democracy is led by wisdom in the deliberative deliberations and Article 1 paragraph (2) of the Constitution, which states that sovereignty is in the hands of the people and is carried out according to the Constitution. Based on these two provisions, Indonesia adheres to direct democracy and indirect democracy. According to Hidayat (2015, interview), the implementation of democracy based 
on the Preamble of the 1945 Constitution is a manifestation of the implementation of indirect democracy which manifests the filling of positions in state institutions, where the election is carried out by the House of Representatives, among others in filling positions for members of the Judicial Commission, Constitutional Court Judge, Supreme Court Judge at the Supreme Court, Member of the General Election Commission and the Election Supervisory Board (Herawati \& Sukma, 2019). Furthermore, the implementation of direct democracy is the embodiment of Article 1 paragraph (2) of the Constitution, namely in the form of general elections conducted by the people directly, to elect the President and/vice President, members of the House of Representatives, members of the Regional Representative Council and members of the Regional People's Representative Council.

Furthermore, according to Hidayat (2015, interview), all democracies in Indonesia, both direct and indirect, are Pancasila Democracy, because Pancasila is an ideology of the Indonesian state which is believed to be true by the Indonesian people. This can be seen in the Preamble to the Constitution of Alenia IV, which affirms to "compile national independence in a constitution of the Indonesian state which is formed in an arrangement of the Republic of Indonesia sovereignty of the people based on: Godhead of the Almighty. " Here, it is clear that the state of the Republic of Indonesia is a sovereign state of people or a democratic state. The democracy implemented is democracy based on Pancasila, or called Pancasila Democracy. This is different model with New Order model of democracy. This democracy contains the notion of democracy that is imbued, encouraged, colored, and based on the Indonesian nation and state, which is imbued and integrated with the noble values of Pancasila.

\section{Searching for Democratic Formats for Multicultural Country}

In order to find the most appropriate format of democracy for Indonesia today, Gafar (2005) proposes an alternative to democracy in Indonesia, namely a workable democracy, which can function and be able to maintain national political stability and create and create an effective government, strong, accountable, built in a society with a very high level of social segregation like Indonesia. The alternative democracy is uncommon democracy. Democracy is not a normal democracy that does not meet the requirements as democracy is understood by people, both normatively and empirically.

In a democracy like this there is one dominant party that is able to outperform other parties. Of course the dominant party is obtained through democratic elections. The dominance of the dominant party is usually manifested in the number of seats around $60 \%$. There are four dominant party characteristics. First, dominant in numbers. This means that the party has a greater number of seats than other parties in parliament. Second, the dominant party is also able to dominate the bargaining position. it means that the party is able to convince its opponents strongly if they bargain, so that a lot of its policies can be accepted and therefore remain in the government seat. Third, chronologically, the dominant party indeed controlled the wheel of government for a long time, not only five or six years, but several decades, as the LDP in Japan and the Congress Party in India (see, Boucek, 2003; Reddy, 2005). Fourth, the dominant party dominates the government. This means that the party is able to master the formation of public policies, ranging from breaking down the public agenda to its implementation. Related to the proposed democratic model, a strong government is needed. A strong government is not identical with an authoritarian government, which runs the government without regard to the rule of law and basic rights of citizens. A strong government is a government that is able to survive in the face of various waves of crisis, and its resilience does not use political rules.

In general, Pancasila democracy which has adopted in Indonesian current constitutional system, has characteristics such as prioritizing consensus agreement, prioritizing the interests of the state and society, no compulsion of will on others, a family spirit, responsibility in carrying out the results of deliberations, carried out with common sense and in accordance with a conscience, and the moral accountability of decisions to God based on the values of truth and justice. In the reform era, the implementation of Pancasila Democracy must also place more emphasis on upholding people's 
sovereignty by empowering the supervision of state institutions, political and social institutions, strict division of authority/powers between executive, legislative, and judiciary institutions and respect for the diversity of principles, features, aspirations, and and multiparty political party programs. The point is that in Pancasila Democracy decisions are taken by consensus through joint deliberations.

According to Maciver (1965), democracy is a form of government that has never been fully achieved. Democracy grows according to its own nature. In line with MacIver's (1965) opinion, Pancasila Democracy is a type of democracy that has actually been adopted in Indonesia since the enactment of the 1945 Constitution. This cannot be separated from the ideology adopted by the Indonesian nation, namely Pancasila. Nevertheless, democracy itself continues to develop in accordance with the conditions and conditions prevailing in the country concerned.

Pancasila democracy is a democracy based on Pancasila. Thus there are five basic values that underlie Indonesian democracy, namely godhood, humanity, unity, consultation/representation and social justice. In addition to the five basic values, it is necessary to consider two other basic values that also underlie Indonesian democracy, namely independence and equality. Independence is defined as freedom of thought and issuing opinions and adheres to one's own beliefs, freedom to unite with fellow friends in achieving a goal and independence to regulate one's own life and life (Soemantri, 2014).

The next basic value is the equation. Independence and equality are basic values that cannot be separated. There are two things that will affect the implementation of Pancasila democracy. First is the philosophy or ideology embraced by nations, and second is globalization as a result of the emergence of technology as a force. The constitution that has become a common agreement plays an important role in the life of society, nation and state. In this regard, what needs attention in detail, especially from state administrators and state government administrators, is that Indonesia is a state based on law, Indonesia adheres to the presidential system, where the President is not responsible to parliament and the ministers are assistants President who is not responsible to parliament (Cipto, 2015).

\section{Conclusion}

The findings show that the most appropriate democracy for the Indonesian state is the Constitutional Democracy based on Pancasila. Based on the provisions of Article 1 paragraph (2) of the Constitution, democracy adopted in Indonesia is a direct democracy whose implementation is in the form of direct elections to elect the President and/or Vice President, Members of the House of Representatives, Members of the Regional Representatives and Members of Representatives Regional People. Based on the provisions in paragraph IV of the Preamble of the Constitution, and indirect democracy/representative democracy, in filling positions in several state institutions, such as the Constitutional Court, Judicial Commission, Supreme Court, Election Commission, Election Supervisory Body whose election carried out by the House of Representatives. For the Pancasila Democracy to be carried out in accordance with the mandate of the 1945 Constitution of the Republic of Indonesia, the participation of all Indonesian citizens is needed. To increase the participation of all citizens in the implementation of the Pancasila Democracy, it is needed seriousness from political parties to carry out their functions, especially in terms of their function as a means of political communication.

The function of political parties as a means of political communication is urgently needed, namely to communicate the aspirations of the people to the government and government policies to the people, so that there is no large gap between the wishes of the people as sovereignty holders and the government as the organizer of the state government. Communication between the people as holders of sovereignty and the people as administrators of the state can be well established, so that a Pancasila democracy can be realized, prioritizing consensus agreement, the interests of the state and society, not forcing the will of others, always overwhelmed by a family spirit, the existence a sense of responsibility in carrying out the results of deliberations conducted with common sense and in 
accordance with a noble conscience, making decisions that can be morally accountable to God Almighty based on the values of truth and justice.

\section{Reference}

Alwasilah, A. C. (2008). Qualitative Research [Indonesian]. Jakarta: Pustaka Jaya

Anwar, C. (2015). Theory and Constitutional Law [Indonesian]. Malang: Equivalent Press

Bastian, B. (2015). World Government Systems [Indonesian]. Yogyakarta: Diva Press

Boucek, F. (2003). Electoral and parliamentary aspects of dominant party systems. In Comparing Party System Change (pp. 109-129). Routledge.

Budiardjo, M. (2008). Fundamentals of Political Science [Indonesian]. Jakarta: Gramedia Main Library

Butt, S. (2015). The Constitutional Court and Democracy in Indonesia. Brill.

Cipto, H. H. (2015). Indonesian Constitutional Law [Indonesian]. Yogyakarta: Cahaya Atma Pustaka

Crouch, H. (1972). Military Politics Under Indonesia's New Order. Pacific Affairs, 45(2), 206-219.

Feith, H., \& Castles, L. (2007). Indonesian political thinking 1945-1965. Equinox Pub.

Gafar, A. (2006). Indonesian politics: Transition to Democracy [Indonesian]. Yogyakarta: Pustaka Pelajar.

Herawati, R., \& Sukma, N.M. (2019). Negative campaign presidential election 2019 on Indonesia national integration. International Journal of Scientific and Technology Research 8(11), 1994-1997

Hidayat, A. (2006). Freedom of Association in Indonesia [Indonesian]. Semarang: Diponegoro University Press.

Horowitz, D. L. (2013). Constitutional change and democracy in Indonesia. Cambridge University Press.

Lev, D. S. (2009). The Transition to Guided Democracy: Indonesian Politics, 1957-1959. Equinox Publishing.

Lindsey, T. (2002). Indonesian constitutional reform: muddling towards democracy. Sing. J. Int'l \& Comp. L., 6 , 244.

MacIver, R. M. (1965). The web of government. New York: Macmillan

Mahfud, M.M.D. (1999). Laws and Pillars of Democracy [Indonesian]. Yogyakarta: Gama Media

Mahfud, M.M.D. (2012). The politics of law in Indonesia [Indonesian]. Jakarta: RajaGrafindo Persada

Marzuki, P. M. (2003). Legal Research [Indonesian]. Jakarta: Kencana

Michels, A., \& De Graaf, L. (2010). Examining citizen participation: Local participatory policy making and democracy. Local Government Studies, 36(4), 477-491.

Moleong, L.J. (2004). Qualitative Research Methodology [Indonesian]. Bandung: Remaja Rosdakarya.

Morfit, M. (1981). Pancasila: The Indonesian state ideology according to the new order government. Asian Survey, $21(8), 838-851$.

Muladi, M. (1997). Human Rights, Politics and Criminal Justice System [Indonesian]. Semarang: Diponegoro University Press.

Nggilu, N. (2015). Law and Constitutional Theory [Indonesian]. Yogyakarta: UII Press

O'Rourke, K. (2002). Reformasi: the struggle for power in post-Soeharto Indonesia (p. 146). New South Wales: Allen \& Unwin.

Parasong, M. A.T. (2014). Preventing the Collapse of the Law State [Indonesian]. Jakarta: Grafindo

Pradityo, R. (2018). Penyelesaian perselisihan internal partai politik secara mufakat dan demokratis/dispute resolution of internal political parties in consensus and democratic. Jurnal Hukum dan Peradilan, 7(3), 375386.

Reddy, T. (2005). The Congress Party Model: South Africa's African National Congress (ANC) and India's Indian National Congress (INC) as Dominant Parties. African and Asian Studies, 4(3), 271-30o.

Saraswati, R., Ristyawati, A., \& Basworo, R.S. (2020). Recent developments and changes in the governance of regional legal products in Indonesia: Supervision, evaluation and clarification mechanisms. International Journal of Innovation, Creativity and Change 12(7), 1-9

Soemantri, S. (2014). Indonesian Constitutional Law Thought and Views. Bandung: Rosdakarya Offset.

Sorensen, G. (1993). Women in Democracy and Democratization: Process and Prospect in A Changing World. Oxford: Westview Press.

Wahyono, P. (1989). Democracy of Pancasila According to the 1945 Constitution, 30-Year State Administration [Indonesian]. Bandung: Faculty of Law, Universitas Padjajaran. 